\title{
Modernismen i spansk poesi
}

\author{
Federico García Lorca og Rafael Alberti \\ mellem postsymbolisme og socialt engagement
}

\section{Modernisme og Spanien}

Anvendelsen af begrebet »modernisme « på den spanske litteratur- og kulturhistorie er vanskelig af flere årsager. Den mexikanske forfatter Octavio Paz ser forholdet mellem samfundsmæssig modernisering og modernistisk poesi som et forhold præget af gensidig afhængighed og modsætning: »den modernistiske poesi har fra starten været en reaktion på og vendt mod det moderne: oplysningstiden, den kritiske fornuft, liberalismen, positivismen og marxismen. ${ }^{1}$ Ved århundredeskiftet var Spanien et relativt tilbagestående land, som først med republikkens indførelse i 1930'erne påbegyndte de økonomiske og politiske moderniseringer, som var gennemført i slutningen af det forrige århundrede i Central- og Nordeuropa. Uden at ville reducere kunsten til en refleks af den samfundsmæssige udvikling kan man sige, at den sociokulturelle baggrund for en egentlig modernistisk kunst i Spanien blev afbrudt med borgerkrigens start i 1936. Modernismen er forblevet et ufuldendt projekt i Spanien.

Brugen af modernismebegrebet i en spansk kontekst bliver desuden vanskeliggjort af, at det spanske begreb modernismo traditionelt er blevet knyttet til bestemte retninger indenfor litteratur og arkitektur op til århundredeskiftet, som i en europæisk kontekst går under betegnelser som symbolisme, art nouveau eller jugend. Og indenfor den spanske litterære kritik og litteraturhistorie har der endvidere eksisteret en mangeårig tradition for at skelne skarpt mellem denne modernismo på den ene side og en såkaldt 1898-generation af spanske forfattere på den anden; en skelnen som først og fremmest bygger på tilstedeværelsen af en eksplicit holdning til politiske forhold og nationale interesser i samtiden eller ej. De senere års litteraturhistorieskrivning har så at sige dekonstrueret denne modsætning ved netop at betone den implicitte sociale protest, som kan læses ind i både den europæiske symbolisme og den spanskamerikanske modernismo.

Endelig er modernismebegrebet heller ikke nogen klar og entydig størrelse i en europæiske kontekst. ${ }^{2}$ Pedro Aullón de Haro, som har leveret et af de me- 
re vellykkede fors $\emptyset \mathrm{g}$ på at genskrive den spanske litteraturhistorie i overensstemmelse med en europæisk standart, lægger sig, i lighed med Octavio Paz, fast på en meget bred beskrivelse af det moderne, som han definerer som »den kulturrevolutionære proces som indledes $i$ anden halvdel af det attende århundrede og afsluttes med den spanske borgerkrig. « ${ }^{3}$ Heroverfor finder vi et anglo-amerikansk modernism-begreb, som f.eks. Anthony Leo Geist definerer som »den kulturelle bevægelse som i den vestlige verden spænder fra de æsteticistiske strømninger i slutningen af forrige århundrede og frem til omkring slutningen af den anden verdenskrig, og som udspringer af den postsymbolistiske repræsentationskrise. $\aleph^{4}$ Geist sætter således nærmest lighedstegn mellem modernismen og avantgardestrømningerne ud fra det han vælger at kalde tegnets repræsentationskrise: »avantgardestrømningerne bliver artikulationen af repræsentations- og referentialitetskrisen; i et ord, tegnets krise.«

Endelig skelner Peter Bürger i Theory of the Avant-garde på sin side skarpt mellem begreberne modernisme og avantgarde. For Bürger indbefatter modernismen de herskende æsteticistiske strømninger omkring århundredeskiftet, herunder symbolismen, der grundlæggende set bygger deres selvforståelse på kunstens adskillelse fra det sociale (l'art pour l'art). For de æsteticistiske strømninger blev kunstens autonomi gjort til et tema i sig selv, og kunsten blev grundlæggende selvreferentiel: » Esteticismen gjorde det træk som definerer kunsten som institution til kunstværkernes essentielle indhold. « ${ }^{5}$ De æsteticistiske strømninger indebar, ifølge Bürger, at selve formgivningen af det kunstneriske udtryk i mange tilfælde slog over i at blive kunstens væsentligste indhold, og han definerer efterfølgende avantgarden i modsætning hertil, dvs. som de strømninger der vender sig mod kunstens autonomi og hele kunstinstitutionen i det borgerlige samfund: »De europæiske avantgardestrømninger kan defineres som et angreb på kunstens placering i det borgerlige samfund. Det, som negeres, er ikke en tidligere kunstform (en stil), men kunsten som institution som er adskilt fra menneskets livspraksis.«

Ud fra det ovenstående er det nu muligt at skelne mellem på den ene side »det moderne « eller »moderniteten « som en sociokulturel bevægelse i den vestlige verden fra midt i 1700-tallet og frem til midten af dette århundrede, og på den anden side »modernisme« som en litterær og kunstnerisk reaktion på kunstens rolle inden for det moderne. Modernismen bliver således at forstå som de kunstneriske strømninger, der, i æsteticismens kølvand, reagerer på det moderne, rationelle og urbaniserede samfund ved at problematiserer kunstens traditionelle rolle i forhold til dette samfund. Modernismen tager en række traditionelle forestillinger om kunst og litteratur op til debat; det gælder f.eks. opfattelsen af kunstværket som et organisk værk, der modstilles det uorganiske, åbne, kollageagtige og fragmenterede, og det gælder forestillingen om det kunstneriske tegns reference til verden, hvor æsteticismens selvreferen114 
tialitet føres videre over i et angreb på såvel sprogets som de ikoniske tegns hele referentialitet. Endelig tager modernismen de æsteticistiske og puristiske kunstopfattelsers tilstræbt apolitiske attitude under behandling, og møder dem med forskellige former for antiartistiske opgør med traditionen og/eller politisk engagerede positioner: ekspressionisme, surrealisme osv.

Da pladsen imidlertid ikke tillader en fremstilling, der går ind i en undersøgelse af samtlige disse forhold, vil jeg i det følgende nøjes med, gennem punktnedslag i periodens litterære produktion, at illustrere udviklingen af det vi kunne kalde den modernistiske repræsentationskrise i Spanien.

\section{7-generationen}

I en spansk sammenhæng falder interessen ud fra denne modernismedefinition først og fremmest på den såkaldte »27-generation« i spansk litteratur og kunst. ${ }^{6}$ Indenfor denne gruppe er det digtere som Federico García Lorca, Rafael Alberti, Jorge Guillén, Pedro Salinas, Gerardo Diego, Luis Cernuda og Vicente Aleixandre som har opnået den største anerkendelse både nationalt og internationalt, men gruppen rummer tillige en meget varieret konstellation af andre kunstnere: f.eks. epikere, kunstmalere, skulptører og musikere. Gruppen er præget af stærke venskabsbånd på kryds og tværs, samt af en eksperimenterende æstetik der forsøger at få de forskellige kunstneriske udtryk til at spille sammen. 27-generationens poematiske udvikling kan skildres som følger:

1. 1920 - 1925 Postsymbolistisk purisme

2. 1925 - 1927 Gongorisme og neokubisme

3. 1928 - 1932 Spansk surrealisme

4. 1930 - 1936 Politisk engageret kunst

Fra en postsymbolistisk purisme i de tidlige tyvere, hvor stort set hele gruppen er under kraftig påvirkning af digteren Juan Ramón Jiménez, bevæger toneangivende dele af gruppen sig i retning af en surrealistisk inspireret ekspressionisme i slutningen af 20'erne, for i 30'erne at give sig hen til en eksplicit socialt og politisk engageret kunst. Blandt digterne gælder det i første omgang Federico García Lorca (1898-1936), Vicente Aleixandre (1898-1984), Rafael Alberti (1902-) og Luis Cernuda (1904-1963), mens f.eks. Jorge Guillén (1893-1984) forbliver tro mod den puristiske kunstopfattelse. Jeg vil i det følgende koncentrere fremstillingen om Alberti og García Lorca, som er de væsentligste, klareste og i øvrigt også tidligste repræsentanter for den generelle udvikling. 


\section{Purismens selvreferentielle universer}

27-generationens tidligste poesi var, som nævnt, bl.a. inspireret af Juan Ramón Jiménez. ${ }^{7}$ Jiménez søger en forenkling af formen der til tider grænser til det stiliserede, for derigennem at gribe en slags poetisk »essens. « Da denne essens imidlertid på én gang er motivet for det evokerede poetiske univers, et resultat af formens stilisering og et rent poematisk ideal, bliver hans poesi grundlæggende selvreferentiel. Et eksempel på dette finder vi i digtet »Vino, primero, pura « fra samlingen Eternidades (1917), som giver et indblik i Jiménez' puristiske projekt. Fem sjettedel af dette digt er helliget beskrivelsen af en kvindes tagen sit tøj af og på for en mandlig betragter: »Hun kom, først, ren,/ klædt i uskyld / Og jeg elskede hende som en lille dreng «, mens den allegoriske mening først ses i tekstens sidste vers: »Og hun tog sin tunika af, / og stod nøgen frem... / Åh, du mit livs lidenskab, nøgne / poesi, du er min for evigt! $\ll^{8}$

Idet digtet læses som en selvreferentiel allegori over digterens søgen efter poesiens rene essens, henvises læseren til at identificere sig med beskuerens maskuline fascination, for ved digtets slutning af kunne overføre den fysiske tiltrækning metaforisk på tekstens poetiske indhold. Digtets centrale udsagn bliver i denne læsning, at den kvindelige skønheds fysiske tiltrækning af hankønnet kan ses som en metafor for digterens længsel efter den rene poetiske essens. Og selve denne essens bestemmes derigennem samtidig som et fænomen af en så flygtig og uudsigelig karakter, at det kun kan opleves metaforisk.

Juan Ramón Jiménez er 27-generationens ubestridte læremester i 20’ernes første halvdel, og en lignende nærmest allegorisk selvreferentialitet kan indlæses i Rafael Albertis og García Lorcas tidlige poesi. Alberti fremstiller i sin første digtsamling, Marinero en tierra (Sømand på land, 1925), barndommens tabte verden ved Cádizkysten. Det er et irrealt, poetisk univers med fantastiske undervandsscenarier befolket med imaginære sømænd og skønne sirener.

I prologdigtet »Sømandens drøm« præsenteres det univers, der udfoldes i resten af samlingen, og drømmen introduceres som centralsymbol i samlingens poetik. Digtet starter med at præsentere sømanden på land som tekstens lyriske jeg: »Jeg, en sømand på min bred../ placeret ved den grå og ferske flod / som munder ud i et andalusisk hav «. ${ }^{9}$ Det lyriske jeg drømmer sig ud på havet, hvor hans drøm personificeres og forelsker sig i sirenen på havets bund. Sirenen bliver fra samlingens første digt beskrevet som digterens drømmemuse, der lever i en anden verden, poesiens og kunstens undervandsverden, som digteren kun kan få adgang til gennem den nævnte drømmerejse. Hermed lancerer »Sømandens drøm« et ledemotiv, som man kunne kalde »poesien er en rejse«, og som tjener som et metaforisk grundskema for hele Albertis tidligste forfatterskab. Når jeg kalder det et grundskema er det fordi det kan varieres og gives mange forskellige former: i Marinero en tierra er det en drøm- 
merejse ud på havet, i La amante (skrevet i 1926 og udgivet i 1927) er det en rejse i bil til Spaniens nordkyst og i hans surrealistiske hovedværk, Sobre los ángeles, er det en indre rejse (skrevet i 1928 og udgivet i 1929). Jeg har andetsteds ${ }^{10}$ skitseret hvordan dette allegoriske grundskema i Marinero en tierra kan transskriberes i en række analogier:

1. hav : land :: poesi : prosaisk verden

2. sømand : hav :: lyrisk jeg : poetisk univers

3. båd : hav :: sprog : poesi

4. drøm : sømand :: inspiration : digter

5. sømand : sirene $::$ digter : muse

6. sirene : hav :: essens : poesi

1. Havets relation til landjorden ligner pr. analogi poesiens forhold til den prosaiske verden: det er en verden for sig, som følger egne lovmæssigheder. 2. »Sømanden på land « står i et forhold til havet som element, der pr. analogi ligner det forhold, digteren har til det poetiske univers: det er et forhold styret af trangen til at trænge ind og intergrere sig i dette univers. 3. Båden står i en relation til havet, som ligner det forhold sproget har til poesien: et vehikel med hvilket universet udforskes. 4. Drømmen er for »sømanden på land, « hvad inspirationen er for digteren: det er den faktor som får ham til at »se«. 5. Sømandens forhold til sirenen ligner digterens forhold til hans Muse: det er den skjulte, feminine kraft, som driver hans projekt. 6. Og endelig er sirenens relation til havet analog med den rolle som den poetiske »essens « spiller i forhold til den poetiske diskurs i Albertis tidlige, essentialistiske digtning: det er den efterstræbte, nøgne sandhed som skjuler sig på bunden.

Federico García Lorca var født og opvokset i Granada og altså ligesom Jiménez og Alberti fra Andalusien, men fra 1918 og frem var han i lange perioder bosat i Madrid på den legendariske Residencia de Estudiantes, hvor størsteparten af 27-generationens kunstnere boede eller havde deres gang. Det andalusiske landskab, provinsens karakteristiske byer og kulturer udgør et centralt ledemotiv i stort set hele hans poetiske produktion, men især i årene fra 1921 til 1927 kommer den andalusiske sigøjnerverden til at repræsentere de særligt poetiske kvaliteter i Lorcas digtning, såsom passionen, dramaet og tragedien. Denne brug af en stiliseret sigøjnerverden som billede på det særligt poetiske finder man allerede i digtsamlingen Poemas del cante jondo, som f.eks. i cyklussen Poema de la Soleá, hvortil digtet »Puñal « hrer: ${ }^{11}$

\section{DOLK}

Dolken 
trænger ind i hjertet

som plovens skær

trænger ned i den golde jord

Nej

Stik den ikke i mig

Nej.

Forskellen til Albertis poesi er tydelig; hvor Alberti bruger kombinationen af det åbne kystlandskab med den ungdommelige glæde som motiv for sin poesi, dér tager Lorca afsæt i det indre Andalusiens tillukkede og dramatiske sider, der gemmer kimen til passionen og tragedien i sig. Lorcas lille tekst rummer mange af de store ledemotiver i hans senere poesi og teater, f.eks. kniven som fallisk symbol og blodet som et fertilitetssymbol, men også antinomier som lys/mørke, sol/måne og overflade/dyb er genkommende tematiske strukturer $i$ hans senere digtning. Disse umiskendelige »lorquismer « er her kombineret med en grafisk tilrettelægning inspireret af den tidlige ultraisme, samt en sproglig kortform der, ligesom hos Alberti, forudsætter læserens etablering af et overgribende motiv. I Lorcas tilfælde er det ligefrem muligt at læse en vis grad af anekdotisk handling ind i cyklussen.

Anvendelsen af sigøjneruniverset som udgangspunkt for en mytologisering af den kreative proces bliver endnu tydeligere i Lorcas nok berømteste værk, Romancero gitano (skrevet mellem 1921 og 1927 og udgivet i 1928). I denne bog skildres modsætningen mellem sigøjneruniverset og den omgivende verden som en tematisk modsætning mellem natur og civilisation, mellem krop og intellekt eller mellem drifts- og realitetsprincippet i en freudiansk terminologi. Samlingens gennemgående centralsymbol er »la pena«, den særlige andalusiske sorg som Lorca selv karakteriserer således:

»Det er ikke angst (angustia) for med sorgen (pena) kan man smile, det er heller ikke en voldsom smerte (dolor) eftersom den aldrig slår om i gråd, det er en længsel (ansia) uden objekt, det er en vild kærlighed til ingenting med en sikker forvisning om at døden (Andalusiens evige bekymring) ånder lige bag døren.« $\ll^{12}$

Candelas Newton relaterer denne »pena« til selve skriveprocessen, idet hun gør opmærksom på at »skriften, fortællingen, altid er en elegisk jamren, thi den virkelige oplevelse (som man skriver om) er fjern. $\ll^{13}$ Således læser Newton hele samlingen ud fra en selvreferentiel synsvinkel, idet hun forstår Lorcas sigøjnerballader som »mytificeringer af den kreative proces. « Samlingen kan på denne baggrund læses som en diskussion af hvordan den utilfredsstillede 
drift skaber en smertelig længsel, der, indenfor de eksisterende rammer, kun lader sig indfri partielt i kraft af kunstnerisk sublimering. Således tages de æsteticistiske strømninger indenfor f.eks. musikken (»Preciosa og vinden«) og billedkunsten (»Zigøjnernonnen«) under ironisk bearbejdning i Newtons læsning, som værende fremmedgjorte, libidinøse virkelighedsfremstillinger. »La pena« bliver en livsattitude (»Balladen om den sorte sorg «), for hvis den udleves direkte er den normoverskridende (»Den utro hustru«) og resulterer i tragisk repression (»Balladen om den spanske Civilgarde«).

Denne livs- og kunstopfattelse kan, indenfor en biografisk tolkningstradition, relateres til Garcías Lorcas tilværelse som skabsbøsse i 20’ernes Spanien. Men hvad der er nok så interessant i denne sammmenhæng, er at se på sprogets rolle i digtningen. Er sigøjnermyten en allegori over det poetiske univers, bliver dette univers fremstillet som værende domineret af »la pena«, dvs. en passion eller sorgfyldt smerte, som også involverer sensualitet, dans og musikalitet. Lorcas »pena « kan således siges at være en poetisk essens på linje med Albertis »sirene.« De repræsenterer begge kvaliteter der ikke kan udtrykkes på anden måde end gennem poesiens skabelse af det poetiske univers. Og dette univers er alene opstået i kraft af digterens manipulation af sproget.

For både Alberti og García Lorca gælder således, at deres tidligste produktion er grundlæggende præget af en puristisk orienteret essentialisme. Det er en evasiv poesi i den forstand at den sigter mod skabelsen af autonome poetiske universer, der kan ses som alternativer til den umiddelbare virkelighed, og hvor digteren som en lille Gud kan iværksætte sine eksperimenter. I forlængelse af den romantiske tradition kan denne poesi læses som en flugt fra den prosaiske verden, en flugt hvorigennem sproget løsrives eller »frigøres « fra dets rationelle fængsel i de kommercielle og magtrelaterede hverdagsdiskurser. Og det er en selvreferentiel poesi, som tenderer mod at lukke sig omkring sig selv og sin egen tilblivelse, idet de skildrede poetiske universer kan læses allegorisk som beskrivelser af poesiens og kunstens tilstræbte autonomi fra den sociale praksis.

\section{Fra neokubistisk gongorisme til reprasentationskrise}

Den i en modernisme-sammenhæng mest interessante kunst opstår ved overgangen fra purismen til en mere avantgardistisk orienteret æstetik. Her udgør årene 1925-26 på flere leder det første vigtige skæringspunkt. Således udgiver filosoffen José Ortega y Gasset i 1925 essaysamlingen Menneskets fordrivelse fra kunsten,${ }^{14}$ hvori begrebet »kunstens afhumanisering « lanceres som en beskrivelse af både den postsymbolistiske purisme og den tidlige avantgardisme, som i spansk og spansk-amerikansk sammenhæng går under betegnelser som 
ultraismo og creacionismo. ${ }^{15}$ Ortega karakteriserer den afhumaniserede kunst ved dens objektivistiske synsvinkel, dens elitære attitude og ved dens »intranscendens «, dvs dens bevidste afståelse fra enhver form for ideologisk, religiøs, politisk eller på anden måde kulturel historisk ambition. I stedet er den »pueril « og »ludisk «. Udgivelsen af Ortegas essays er en milepæl i den forstand at de meget præcist beskriver nogle tendenser i den forudgående litteratur og kunst, og de kan dermed siges at markere startskuddet til noget andet.

Indenfor litteraturen gav de nye æstetiske tendenser sig i første omgang tilkende i form af interessen for barokdigteren Luis de Góngora y Argote. I april 1926 tog en gruppe digtere og billedkunstnere initiativ til at forberede festligholdelsen af Góngoras 300 års dødsdag det følgende år. Góngoras poesi med dens latiniserede syntaks, komplicerede metaforik og hele elitære »culteranismo « ligger meget langt fra både Juan Ramón Jiménez’ simplistiske essentialisme og fra de tidlige avantgardestrømningers frie former, som havde haft en dominerende indflydelse i årene forud. Og alligevel kan man sige at den kortvarige dyrkelse af neogongorismen på én gang repræsenterer en kulmination af de puristiske tendenser og samtidig introducerer sin egen modsætning. Fascinationen af Góngoras hermetiske formsprog markerer således en ultimativ puristisk insisteren på kunstens adskillelse fra verden og en kulmination af æsteticismens tendens til at lade udtrykkets form blive kunstens indhold. Men samtidig betragter en del af de involverede digtere de gongoristiske former ud fra en avantgardistisk æstetik som sætter læseren og læseakten i centrum, og som underkender »værkets« helhedskarakter. På den baggrund kan neogongorismen forstås som den strømning der udløser repræsentationskrisen, og som dermed i poematisk forstand fører over i den spanske surrealisme.

I den forbindelse fremlægger ophavsmanden til hele Góngora-initiativet, digteren Gerardo Diego, nogle interessante overvejelser i et essay så tidligt som i 1924. Her foreslår Diego at de unge digtere må udvikle deres læsning af barokdigteren i overensstemmelse med deres egen poetik, således som symbolisterne har gjort det før dem. Og nøglen hertil er for Diego at tage mesteren på ordet: »Ofte bevirker hans (Góngoras) særegne syntaks at sætninger bliver skåret i stykker og delt op på en sådan måde at de, helt bortset fra hvad de betyder i sig selv, fyldes med ansporende betydningsmuligheder. ${ }^{16}$ Som eksempel nævner han Góngoras vers »La playa azul, de la persona mía « (direkte oversat: min persons blå strand) som i sin oprindelige kontekst kan læses som en traditionel spejlmetafor for havet, idet det er en fortsættelse af versene »el día / que espejo de záfiro fué luciente«, hvilket resulterer i følgende parafrase: »dagen hvorpå den blå strand var som et lysende safirspejl for min person. « ${ }^{17}$ Det som interesserer Diego er imidlertid ikke versets grammatiske eller intenderede betydning, men den stik modsatte operation, hvor »la playa azul« (den blå strand) bliver et creationistisk billede på »la persona mía« (min person). 
Hans argument for denne operation er, at »skønt den synsvinkel der betragter verset $\mathrm{i}$ dets falske isolerede betydning ikke siger det som Góngora ønskede at sige, så er resultatet af ubeskrivelig skønhed, og... det står jo dér. Diego argumenterer for at den ugrammatiske og ikke-intenderede betydning ligger i teksten på samme måde som naturens luner frembringer former, som den menneskelige fantasi kan bruge som udgangspunkt for at skabe kreativ betydning: sære klippeformationer og knudrede stammer bliver materiale for beskuerens fantasi. Hans position er interessant, ikke kun fordi han med denne æstetik foregriber et fænomenologisk og modtagerorienteret kunst- og litteratursyn, men også fordi der er grund til at mene, at denne æstetik ligger bag store dele af generationens Góngora-interesse. Og læst på denne måde bliver Góngora-indflydelsen det vehikel, der udløser den modernistiske repræsentationskrise. Idet poetikken åbner op for at tilsidesætte sprogets grammatiske rationalitet og semantiske kohærens glipper referentialiteten. Sproget truer med i bedste fald at blive en tom form, i værste fald utroværdigt, falsk eller direkte løgnagtigt.

\section{García Lorcas og Albertis poesi}

Årene 1925-27 er for García Lorcas vedkommende præget af det nære venskab med Salvador Dalí, som i tyvernes første halvdel også boede på Residencia'en. Omkring 1925-26 havde Dalí for egen regning kastet sig over det neokubistiske maleri, og Lorcas »Oda a Salvador Dalí « fra 1926 er en af de tekster som bedst giver indsigt i periodens kunst- og litteraturopfattelse: ${ }^{18}$

En rose i den høje have som du begærer.

En rose i den rene jernsyntaks.

Bjerget afklædt den impressionistiske tåge.

Gråtonerne udforsker sine yderste grænser.

De moderne malere i deres hvide atelierer, afskærer kvadratrodens aseptiske blomst.

I Seinens vande får et isbjerg af marmor

vinduerne til at fryse til og vedbenden til at spredes.

Odens to indledende strofer skaber en præcis forbindelse mellem de to kunstneriske udtryksformer, poesien og maleriet. Rosen kan læses som den creationistiske rose, som Huidobro lod blomstre i sit digt (se note 15), og som her i García Lorcas karakteristik af Dalí vokser ud af den »rene jernsyntaks « i den første strofes afsluttede sætningsemner. Sprogets logiske, regelbundne syntaks er digterens konstruktionsmateriale i den rent intellektuelle proces hvorigen- 
nem poesien bliver til (de høje haver), ligesom de geometriske former (kvadratrodens blomst) udgør grundelementet i den kubistiske malers formsprog. Paris nævnes (Seinen) som arnested for denne kunst, der arbejder i kubismens foretrukne gråtoner, og som driver kunstens puristiske afsondring fra verden til det yderste (det hvide aseptiske univers). Og samtidig er det en kunst som lægger afstand til de sentimentale impressionistiske universer (den impressionistiske tåge) der prægede den forudgående sensymbolistiske kunst og poesi.

I min Ph.d.-afhandling har jeg sammenlignet Albertis tidlige poetik i $M a$ rinero en tierra med en impressionistisk teknik ${ }^{19}$ fordi det overlades læseren at sammenstykke de små canciones-fragmenter til et sammenhængende univers på samme måde som det impressionistiske billede først bliver til en helhed på betragterens nethinde. García Lorca synes at trække på den samme forbindelse, når han med slet skjult sarkasme i strofe fem skildrer den nye æstetik således: »Sømænd som ikke kender vinen og mørket / halshugger sirener i have af bly« (»OSD«). Sømanden, billedet på Albertis lyriske jeg i Marinero en tierra, sendes i García Lorcas tekst ædru og under dagens sol ud på havet for at »halshugge sirener «, altså likvidere centralsymblet for Albertis neopopulære eller sensymbolistiske poesi. Et tilsvarende, omend mindre dramatisk, billede på den samme poematiske udvikling, finder vi i samme teksts syvogtyvende strofe: »Jeg besynger den lille sirene som besynger dig / overskrævs på en cykel af koraller og skaller « (»OSD «). Musen for den moderne kunst kører på cykel: hun har lagt havuniversets impressionistiske tåger og sentimentale nostalgi bag sig, og er blevet en moderne kvinde.

Det interessante er nu, at vi finder en helt parallel udvikling hos Alberti selv, som i digsamlingen Cal y canto (skrevet 1926-28, udgivet 1929) foretager en systematisk destruktion af en række både private og kollektive myter. Synspunktet synes at være, at hvis kunsten skal leve op til at være et selvgyldigt og autonomt domæne, bør den ikke støtte sig på disse mytologiske komplekser som en slags krykker. I samlingens tidligste tekster destrueres det maritime univers fra hans neopopulære purisme gennem inddragelsen af elementer fra det moderne storbyunivers. Således finder vi i digtet $» D e$ tre sireners drøm« tre sirener forvandlet til moderne storbykvinder »cortas las faldas, cortas las melenas « (korte skørter, kort hår) helt parallelt med Lorcas cyklende sirene. I andre tekster udsættes en række traditionelle topoi fra den klassiske og kristne mytologi for en sarkastisk profanering ved at blive fokuseret på baggrund af moderniteten (f.eks. »Venus i elevator «), og i atter andre ophøjes selve den sproglige formgivning til at være poesiens væsentligste indhold (f.eks. »Araceli «). Og dette foregår i et sprog der langt hen ad vejen har en tilstræbt lighed med Góngoras komplicerede syntaks og sindrige metaforik.

Denne eufori, og den optimistiske tro på den moderne storby med dens rationalitet og geometri, varer imidlertid kort. Allerede i romancerne i Cal y can- 
to's tredie del, begynder der at melde sig en anden tone i teksterne. Det er en mere desperat tone, der synes at have mistet troen på at den sproglige form $\mathrm{i}$ sig selv kan kompensere for tabet af det poetiske univers, hvorigennem det lyriske jeg tidligere momentant og fragmentarisk kunne genskabe den tabte barndoms uskyld og glæde. Og i disse tekster begynder den moderne storby at skifte karakter. Fra at være et moderne slaraffenland for formens realisering, bliver storbyen et truende og destruktivt univers. Denne udvikling ses måske klarest $\mathrm{i}$ »Ballade som mistede båden«, hvor sømanden er faret vild i en fjendtlig by: ».... en sømand, / med de olivenfarvede $\varnothing$ jne / oprørt af vin og skygge, / leder, fortøjret til vindens / lange og natlige hale. $\ll^{20}$

Sammenligner man denne beskrivelse af sømanden med García Lorcas neokubistiske sømænd i »Oda a Salvador Dalí« bliver det tydeligt at der er tale om et modbillede. Hvor Lorcas sømænd »ikke kender vinen og mørket« har Albertis sømand øjnene »oprørt af vin og skygge «, hvor Lorcas sømænd er på havet, dvs integrerede i deres (poetiske) element, der er Albertis sømand en fremmed i byen, og hvor Lorcas sømænd endelig er engageret i et bevidst forehavende, nemlig at »halshugge sirener i have af bly, « dér er Albertis nye billede af digteren én som leder i mørket. Albertis ballade fortsætter brugen af den gongoristiske syntaks og metaforik, der imidlertid nu fremstilles selvreferentielt i billedet af byens labyrintiske gader: »Og hvor er havet? Hjørner / der stikker, spidser uden søvn, / sørgelige trappetrin / ligger døde på jorden / og en malstrøm af rullesten / høster hans kolbøtte, blind « $(C Y C)$.

I denne læsning, hvor byens geometri bliver et billede på den barokke syntaks, destruerer den overdrevne fokusering på den sproglige form det sensymbolistiske poetiske univers. Sproget er ikke længere blot et materiale for konstruktion, som i Lorcas neokubistiske »rene jernsyntaks «, det er også labyrintisk, truende og destruktivt, og denne destruktion erfares af det lyriske jeg som en mangel, et fravær. Sømanden kan ikke finde hverken sin båd eller havet, og havets og bådens fravær bliver symboler for meningens fravær. Dette meningstab beskrives dernæst i form af en ny metafor, vinden, den ultimative destruktive tomhed, der endelig med en vis selvironi refererer tilbage til balladens egen versfinale alliteration på 's': »En susen af udlyds-esser / vindenes alfabeter, / fastnaglede, sønderriver mure / og flår tage løs. $\ll^{21}$

Den gongoristiske poetiske diskurs har udviklet sig til at udgøre en trussel mod det lyriske jegs integritet som digter, og truer derfor med at lamme hans udtryksfærdighed og kommunikationsevne: ».... Lænker / af regn og døde krybdyr, / en hæl af rimfrost mod læberne, / næver af salpeter og is, / binder ham, mens han drejer rundt, til skyggerne, / på fødder, skrig og ekko « $(C Y C$, p.332). Men samtidig med at det lyriske jeg føler et meningstab ved sammenbruddet af dette univers, så rummer den nye poetiske diskurs sin egen ekspressive kraft. Denne nye tekststrategi, der betjener sig af en udpræget visuel me- 
taforik, kommer til sit måske klareste udtryk i digtet »;Eh, los toros!« (Pas på! Tyrene!). Her beskrives naturelementernes rasen metaforisk som en tyrefægtning (eller omvendt), og i tekstens tredie og sidste strofe står tyren udmattet og rådvild overfor sin skæbne: »Sorte bylt, hvorhen / uden kurs, hvis ingen sover, / hvis blodet i spring / maler skrig på væggene? (CYC, p. 334).

Tyrefægtningsmotivet har, både af Alberti og af andre fra hans generation, tidligere været brugt selvreferentielt som en metafor for det lyriske jegs kamp med poesiens genstridige materiale. Indenfor denne metaforiske ramme identificerer det lyriske jeg sig med tyrefægteren, der skal dominere de ukontrollable naturkræfter i bæstet. Men i denne tekst sker der noget andet. Det lyriske jeg identificerer sig i stedet med det rådvilde dyr, og sproget begynder, under indtryk af den følgelige mangel på kontrol, at male sine egne billeder, jvf. synæstesien hvor »blodet i spring maler skrig på væggene.« Dette ejendommelige billede kan imidlertid føres tilbage til García Lorcas digt »Reyerta « (Strid) fra Romancero gitano hvor en knivkamp mellem sigøjnere beskrives: »Stridens tyr / klatrer op ad væggene. / Engle med store vinger / af Albacete-knive. $\ll^{22}$

Lorcas billedsprog er dramatisk, men samtidig klart og forståeligt i en forfatterskabsintern kontekst. Stridens tyr, som klatrer op ad væggene repræsenterer de ophidsede temperamenter, mens englene med vinger af Albacete-knive dels henviser til selve knivkampen, ${ }^{23}$ dels henviser til dødens indtræden i form af dødsengle. I et senere essay, »Duendens leg og teori «, behandler García Lorca den særlige andalusiske duende, som får smerten frem i kunsten og som er nødvendig for flamenco-sangen. I en passage beskriver Lorca hvordan en firsårig gammel kvinde vandt en dansekonkurrence, hvori der også deltog mange unge, smukke og dygtige kvinder og mænd. Den gamle kvinde vandt alene ved at knejse med hovedet og give et enkelt tramp i gulvet, hvilket Lorca forklarer således: »i dette selskab af muser og engle, smukke former og smukke smil, måtte hendes døende duende, som slæbte sine vingers rustne knive hen ad jorden, simpelthen vinde. ${ }^{24}$ Således forbliver Lorcas billedsprog $i$ »Reyerta« forankret $i$ en omfattende og sammenhængende symbolik, mens Alberti, på sin side, river Lorcas billede ud af sin kontekst, forstærker det og bruger dets rent sanselige styrke i en ganske anden tekstlig strategi.

Det fremgår imidlertid af Lorcas breve fra omkring 1927-28, at han, samtidig med at han sarkastisk afliver Albertis muser, også selv er ved at blive grundigt træt af sit eget sigøjnerunivers. I et brev til den katalanske kritiker Sebastiá Gasch skriver Lorca således i september 1928: »Imidlertid interesserer den [Romancero gitano, HLH] mig ikke længere, eller næsten ikke. Den døde på den kærligste vis mellem mine hænder. Nu har min poesi taget en endnu skarpere kurs, $\ll{ }^{25}$ og $\mathrm{i}$ et andet brev skriver han om sine to nyeste prosadigte »Nadadora sumergida« (Svømmepige gået til bunds) og »Suicidio en 
Alejandría (Selvmord i Alexandria): »De modsvarer min nye spirituelle måde at skrive på, den rene og skære følelse afskåret fra den logiske kontrol; men, pas nu på! Med en utrolig poetisk logik. Det er ikke surrealisme, hold fast i det, den klareste bevidsthed lyser i dem. $\ll^{26}$

»Suicidio en Alejandría« er en talleg sammenflettet med en simpel kærlighedshistorie, mens »Nadadora sumergida « for hovedpartens vedkommende består af en enetale i førsteperson til en vis »grevinde. « Jeg-personen forsøger at retfærdiggøre sig i forhold til et tidligere kærlighedsforhold, hvis ophør har gjort ham klogere på livet, - og på kunsten:

»Siden da opgav jeg den gamle litteratur, som jeg havde dyrket med stor succes. Det er nødvendigt at nedbryde det hele for at dogmerne kan lutres og normerne kan få en ny glans. Det er nødvendigt at elefanten får agerhønseøjne, og agerhønen får enhjørningshove.«

Det står klart for García Lorca at det er nødvendigt for ham at renovere sit eget poetiske univers (at elefanten får agerhønseøjne, og agerhønen får enhjørningshove), men det er tilsyneladende også nødvendigt for ham at forholde sig til Albertis poetiske udvikling. For bag »Grevinde $\mathrm{X}$ «, som er den i titlen nævnte svømmepige og som i tekstens sidste afsnit findes opskyllet på stranden med en gaffel i nakken, gemmer sig to unge piger fra Albertis Cal y canto, jvf teksterne »Svømmepigen « og »Til Miss X, begravet i vestenvinden.«

De to digtere forholder sig således løbende til hinanden gennem deres poetiske udvikling, dog hovedsageligt på en sådan måde at Alberti går på hugst i García Lorcas righoldige billedflora, mens Lorca på sin side morer sig med at aflive det ene efter det andet af Albertis centrale poetiske motiver. Det gælder endvidere for begge digtere at de i årene 1926-27 er ved at bevæge sig ind $i$ en periode, hvor det formsprog som de har betjent sig af i den hidtidige digtning ikke længere slår til eller føles adækvat. Hvor der for Albertis vedkommende er tale om at digteren føler at de neogongoristiske eksperimenter truer med at tømme hans poesi for relevante eller vedkommende livserfaringer, er der for García Lorcas vedkommende tale om det andalusiske sigøjnerunivers er ved at blive lige lovligt folkloristisk, og at han søger at trænge ind til poesiens mysterium ved i højere grad at bryde med traditionen og insistere på den rent sproglige og intellektuelle konstruktion. For ingen af digterne er der i udgangspunktet tale om at de arbejder ud fra en bevidst surrealistisk æstetik, men det skal dog bemærkes at García Lorcas ovenfor citerede afstandtagen til surrealismen, i modsætning til hvad der antages i store dele af Lorcaforskningen, ikke kan overføres på digterens avantgardistiske hovedværk, Poeta en Nueva York, men er møntet på nogle tidligere og anderledes ludiske tekster. 


\section{Fra surrealistisk reprasentationskrise til socialt engagement}

I Spanien eksisterede der ikke en surrealistisk gruppe der var samlet omkring et program eller en bevidst og fælles poetik, sådan som f.eks. i Frankrig. En sådan gruppe eksisterede på de Canariske Øer, men forbindelsen til den iberiske halv $\emptyset$ var meget sparsom. Indenfor det madrilenske litterære miljø tog surrealismens indflydelse således først og fremmest form af en række tilsyneladende tilfældigt sammenfaldende personlige kriser for en række af bevægelsens mest fremtrædende medlemmer: Rafael Alberti, García Lorca, Vicente Aleixandre og Luis Cernuda. En tråd i Anthony Leo Geists arbejde har gennem en årrække været at påpege, hvordan disse tilsyneladende individuelle reaktioner ikke bare kan ses som udtryk for en fælles poematisk orientering, men også som helhed kan læses i lyset af den politiske udvikling. ${ }^{27}$

Det har i årevis været diskuteret hvorvidt man overhovedet kan tale om surrealisme i forbindelse med 27-generationen, men i løbet af 1980'erne udkom en række behandlinger af emnet som generelt har bekræftet brugen af begrebet, såvel indenfor litteraturen som indenfor malerkunsten. ${ }^{28}$ Betegnelsen $»$ surrealisme « kommer dermed i det følgende til at repræsentere den 180 graders vending som indtræder i kunsten omkring 1928-29 som et opgør med purismen. Vendingen angår både kunstens formsprog og hele dens orientering. Hvor purismen forudsætter en udskilning af kunsten fra det sociale, dér forstår surrealismen sig selv som anti-artistisk strømning. Hvor purismen søger en intellektuel konstruktion af poesien som et kunstnerisk autonomt værk, dér søger surrealismen det spontane, det irrationelle, det dissonante og det provokerende. Man kan således sige, at den surrealistiske vending i Spanien konkret udmønter sig i 27-gruppens løsrivelse fra Juan Ramón Jiménez' og José Ortega y Gasset's protektion: »Den nye definition på en spansk surrealist kunne være denne: én som skcendes med Juan Ramón Jiménez.«"29

\section{Rafael Alberti}

Efter at Alberti i Cal y canto havde kæmpet mod den tomhedsfornemmelse som de gongoristiske formeksperimenter efterlod, tager han i Sobre los ángeles ${ }^{30}$ forholdet mellem sprogets udtryks- og indholdsside op til behandling. Alberti angriber bl.a. forestillingen om det poetiske sprogs motiverede relation mellem udtryk og indhold, og forestillingen om den særlige ægthed, som udspringer heraf.

I digtet »Den ubeboede krop« bruger han splittelsen mellem krop og sjæl til metaforisk at skildre splittelsen mellem udtryk og indhold: »Jeg rev dig ud 
af min krop, / jeg, med glødende kul. / - Gå nu! (SLA, p.390). Den puristiske renselsesproces, der skulle sikre det kunstneriske sprogs adskilthed fra normalsproget, skildres metaforisk i billedet af skærsildens glødende kul. Men i stedet for uddestilleringen af en ren poetisk essens, resulterer processen i fordrivelsen af al form for substantielt indhold fra den poetiske diskurs, som, på sin side, bliver ladt tilbage som en sort sæk der hænger og svinger i det tomme vindue: »Der var kun min tomme krop, / en sort sæk, ved vinduet« $(S L A)$.

Denne negering af poesiens motiverede forhold mellem udtryk og indhold udgør en trussel mod den poetiske diskurs' oprindelige ærlighed og troværdighed. Den poetiske diskurs tenderer mod at vende tilbage til normalsprogets arbitraritet, og hverdagssprogets diskurser kan bruges til både løgn og bedrag. Derfor opstår der en grundlæggende mistillid til sprogets troværdighed og kommunikative evne i første del af Sobre los ángeles. I digtet »Den forløjede engel « erklærer det lyriske jeg sig besejret af ordet: »Jeg blev tilintetgjort, / jeg, uden vold, / med honning og ord, « og i digtet »Bedrag « gentages dette tema: »Nogen bagved, bag din ryg, / som holder dig for øjnene med ord « (SLA, p.400). Denne mistillid til sproget som et middel til kommunikation og gensidig forståelse i samlingens første del, determinerer diskursens korte, abrupte form, som leder udsigelsen i retning af tavshed. Samtidig etablerer denne mistillid en metaforisk forbindelse mellem udtryksplanets afkortede form og en række semantiske isotopier omkring begreber som tomhed og fravær. Man kan således sige, at mens det motiverede forhold mellem udtryk og indhold angribes selvreferentielt, så har forbindelsen mellem de to planer aldrig været stærkere end netop her hvor poesien i traditionel forstand synger sin svanesang. Men i modsætning til Albertis tidligere poesi, er der i Sobre los ángeles tale om at det motiverede forhold mellem udtryk og indhold er negativt defineret: mens udtrykkets kortform glider mod tavsheden, udtrykker indholdsplanet umuligheden af et poetisk projekt, der ønsker at give ord til kærligheden, skønheden og glæden. I stedet fyldes det poetiske univers af dødbringende substanser, som paralyserer det lyriske jegs sanser.

Hen mod slutningen af samlingen indtræder der imidlertid afgørende forandringer indenfor både udtryks- og indholdsplanet. På indholdsplanet transformeres fraværs- og tomhedsisotopierne til et kaos af afskyvækkende og »urene« elementer: ådsler, affald og ekskrementer. Og på udtryksplanet glider de knappe vers og korte strofer over i de lange versículos, dvs. nogle meget lange og urimede vers, som man f.eks. finder dem i Bibelen. På niveauet for den poetiske udsigelse, som i samlingens første del bevægede sig mod tavsheden, indtræder pludseligt en voldsom insisteren på kontakt og kommunikation, bl.a. udtrykt i en hel række flertals imperativer: »ved « (se), »mirad« (betragt), »buscad « (søg) og »acordaos« (husk) osv. Et uddrag af digtet »De hæslige engle« kan tjene som eksempel (SLA, p.443): 
Se!

$\cdots$

Hvis I vover at tage et skridt,

vil de kommende århundreder erfare, at vandets kvalitet viser sig bedre, jo flere grave og mudderhuller landskaberne skjuler.

Betænk:

Det udsagn har været falsk, at en strikke om halsen er noget ubehageligt, og at maj måned er begejstret for svalens ekskrementer.

Denne nye poetiske diskurs konfronterer en puristisk kunstopfattelse, der måtte betragte kunst og litteratur som ikoniske repræsentationer af nogle ideelle eller essentielle kvaliteter. I stedet for creationisternes rent konceptuelle univers, hvori Huidobro emblematisk lod sin rose blomstre (se note 15), erkender det lyriske jeg i anden del af Sobre los ángeles eksistensen af den virkelig verden. En verden hvor roserne er ormædte, men virkelige: »Men jeg siger jer: / En rose beboet af kålorm er mere rose end en, / der pranger over denne femtenårige månes visne sne« (SLA, ibid.).

En rose »er mere rose« når den er ormædt, dvs. når den er virkelig, end når den blot tilhører et fiktivt univers, der er resultatet af en kreativ, intellektuel konstruktion (denne femtenårige månes visne sne). Denne insisteren på et direkte referentielt forhold til verden sætter spørgsmålstegn ved det poetiske sprogs traditionelle fiktionalitet. Den ormædte rose og anerkendelsen af virkelighedens betydning for det poetiske eller kunstneriske projekt er et første forsøg på at generobre sproget som et kommunikationsinstrument, et redskab for mennesker til at tale om den virkelige verden. Idet det lyriske jeg erkender nødvendigheden af endegyldigt at stige ned fra creationismens og purismens idealistiske tinder, appellerer han til englene - eller er det læserne? - om at destruere dette »onde ord « som digteren, altså han selv, hænger op over det fiktive univers' flydende landskaber: »Omsider begynder vi nu at synke. / Det er på tide at I giver mig hånden / ... og dræber mig dette onde ord, som jeg vil / hænge op over det land som smelter bort. «11

I årene 1929-30 skriver Alberti yderligere to digtsamlinger som henregnes til hans surrealistiske periode. Den ene er Sermones y moradas (Prædikener og boliger) som i store træk fortsætter diskursen fra Sobre los ángeles' sidste del, og den anden er Yo era un tonto y lo que he visto me ha hecho dos tontos (Jeg var en tosse, og det jeg har set har gjort mig til to tosser), der tager scener og handlingsfragmenter fra den sort/hvide stumfilm som sit materiale, og hvis titel stammer fra barokdigteren Calderón de la Barca. Men fra omkring 1930 skifter Albertis poetiske kurs igen radikalt, denne gang i retning af en poetisk diskurs, der fastholder et direkte referentielt forhold til den sociale og politiske 
samtid som en absolut læserforudsætning. I digtsamlingen Poeta en la calle (Digter på gaden), der samler digte fra tiden 1931 til 1935, finder vi således en række tekster der forholder sig til aktuelle begivenheder såsom landarbejdernes jordbesættelser i Spanien, oprørsbevægelsen på Cuba, den sociale nød i Extremadura-provinsen og de asturiske minearbejderes revolution i 1934.

\section{García Lorca}

Omend García Lorcas poesi ikke umiddelbart i sin helhed lader sig læse selvreferentielt, finder man en række vigtige indikatorer for at repæsentationsproblematikken også har stået i centrum for hans poematiske udvikling. I den ovenfor nævnte »Ode til altrets allerhelligste sakramente« diskuterer Lorca således forholdet mellem den rene, afhumaniserede kunst og den »beskidte«, humane virkelighed i en katolsk sakramental metaforik. Hvor Gud og Kristus repræsenterer det rene ideal, som er »død og korsfæstet / på grund af det svedende menneskes urene ord, « dér repræsenterer Eva og syndefaldsmyten referencen til det kropslige, kødet og driften. I digtets fjerde del, som netop er tituleret »Carne « (kød) og som tematiserer syndefaldet, lyder det således: »Det er nødvendigt at systolens og diastolens rytmer [dvs kroppens/hjertets pulserende rytme, HLH] / tilsmudser himlens umenneskelige rødme. $\ll^{32}$

Scenen er nu sat for den rehumanisering af Lorcas poesi, som finder sted i Poeta en Nueva York. ${ }^{33}$ Denne digtsamling blev skrevet under Lorcas første udlandsrejse 1929-30, og indeholder skildringen af et rystet og stærkt identitetssvækket lyrisk jeg i et eksperimenterende formsprog. Henrik Rasmussen har i sin nys udgivne gennemgang af Lorcas lyrik fra 1929 til 1936, Sandhedens maskespil, foretaget en nærlæsning af udvalgte tekster fra denne digtsamling ud fra dannelsesrejsens perspektiv, hvorved der bliver indlæst et forløb i samlingen. ${ }^{34}$ If $\varnothing$ lge HR gennemløber samlingen følgende tematiske faser: 1. mødet med storbyen, 2 . flugten fra byen, hvor erfaringerne bearbejdes, 3. tilbagevenden og konfrontation med byen, og 4 . afrejse med ny erkendelse.

Rehumaniseringen tager således afsæt i det lyriske jegs eksistentielle krise ved konfrontationen med den moderne storbys afhumaniserede landskab. Den tidligere organiske, mytologiserede sammenhæng mellem natur og menneske i sigøjneruniverset, samt den problemfri anvendelse af den poetiske tradition i skildringen af den andalusiske kultur, viser sig inadækvate overfor den udfordring, som mødet med den moderne metropol stiller digteren. Digteren f $\varnothing-$ ler sin identitet truet af byens uoverskuelighed, de uorganiske materialer, de fremmedgjorte omgangsformer og af den anonyme mængde. Det poetiske univers kommer derfor til at bestå af en række løsrevne billeder og ubehagelige, truende og livsfarlige elementer. 
I forlængelse af María Millán arbejder Henrik Rasmussen med tre forskellige syn eller stemmer i samlingen: en fortidig uskyldig, en nutidig lidende og en fremtidig frigjort stemme. ${ }^{35}$ Hos Rasmussen svarer de tre stemmer tildels overens med dannelsesrejsens tre faser, før, under og efter, dog således at de alle tre artikuleres samtidig fra den lidende stemmes her-og-nu-situation, som i digtet »Landskab med mængde der brækker sig«: »Dette blik var mit engang, men det er det ikke mere... / Jeg forsvarer mig med dette blik ... / Jeg, en digter uden arme, fortabt i menneskemængden der brækker sig. « ${ }^{36}$ Det lyriske jeg føler sig fortabt, fysisk lemlæstet og handlingslammet (digter uden arme), stillet overfor storbyens anonymitet, der skildres i det groteske scenarium med menneskemængden der brækker sig. Men samtidig beskytter det lyriske jeg sig med et blik som ikke længere er hans, dvs barndommens uskyldige blik fra før jeg'et fik kendskab til modernitetens fordærv. Det er det blik, der får det lyriske jeg til at hæfte sig ved den uretfærdighed og udbytning som de svage udsættes for: børnene, dyrene og de sorte. På den baggrund erkender det lyriske jeg at det er nødvendigt at justere forholdet mellem syn og stemme, eller anderledes sagt, at etablere et nyt forhold mellem tegn og verden, som kan udtrykke denne nye erfaring. Dette udtrykkes i en krop/sjæl-metaforik, der ikke er fjern fra Rafael Albertis poetiske diskurs i Sobre los ángeles. Således skriver Lorca i digtet »Din barndom i Menton «: »Men jeg må søge din lunkne sjæl i krogene, / din sjæl uden dig, som ikke forstår dig, / med en tilbageholdt Apollons smerte / hvormed jeg knuste den maske du bærer. ${ }^{37}$

Det lyriske jeg må forsøge at genfinde sin egen identitet som har været forvist (sjælen i krogene) og som derfor kun er svag (lunken) og fremmedgjort fra jegets egen krop (din sjæl uden dig, som ikke forstår dig). Det som ansporer til denne søgen er »en tilbageholdt Apollons smerte, « hvor Apollon, i forlængelse af García Posada, kan læses som emblem for den homosexuelle kærlighed, altså en homosexuel utilfredsstillet drift. ${ }^{38}$ Driften har knust den maske, bag hvilken det lyriske jeg hidtil har gemt sig. I Lorcas tidligere poesi har det lyriske jeg holdt sigøjneruniversets forskellige personer og stemmer op foran sig som masker, med hvilke han opførte dramatiske scenarier som metaforisk mimede det lyriske jegs konflikt med verden. Men herved blev det lyriske jegs egen identitet (sjælen) forvist til en metaforisk skyggetilværelse (i krogene). Men masken, dvs sigøjneruniversets metaforiske form, frigjorde sig og antog en selvstændig eksistens (krop uden sjæl), hvorved det lyriske jegs homosexuelle erfaringer (sjælen, indholdet) blev fremmed overfor det (din sjæl uden dig, som ikke forstår dig). ${ }^{39}$ Med andre ord reduceredes sigøjneruniversets »pena« til en folkloristisk kolorit, hvorved den mistede sin metaforiske reference til en anden smerte, nemlig den homosexuelles identitetskonflikt i et machistisk samfund. Formen (sigøjneruniverset) bliver til indhold, og poesien 
trues af et generelt indholdstab. Men idet masken brydes, må det lyriske jeg konfrontere sig direkte med verden, erkende sin identitet og tage de konflikter dette indebærer, som her i teksten »Din barndom i Menton «: »O ja! Jeg elsker! Kærlighed, kærlighed! Lad mig! / Lad dem ikke lukke min mund, de som søger / Saturns hvedeaks i sneen / eller kastrerer dyr for (at komme i) en himmel, / (som er en) klinik og anatomiens urskov. «0

Det lyriske jeg er imidlertid godt klar over at det ikke er nogen enkel sag at tale modernitetens Mekka midt imod, og kan kun med besværgelser håbe at repressionens og dødens kræfter (»dem«) ikke formår at lukke hans mund. Ligesom den fortidige stemme kun var tilstede som en måde hvorpå det lyriske jeg så sin aktuelle virkelighed, således er den fremtidige, frigjorte stemme også kun tilstede som et håb eller en drift, uden at den på noget tidspunkt realiseres. Den er tilstede som et perspektiv om en frigørelse, som i »Dobbeltdigt fra Lake Eden «: »Men jeg søger hverken verden eller drøm, guddommelige stemme, / jeg søger min frihed, min menneskelige kærlighed / i den mørkeste afkrog af brisen ingen vil kendes ved. $\ll^{41}$

Det perspektiv om frigørelse som formuleres er ikke først og fremmest et perspektiv om politisk frig ørelse rettet mod verden eller en romantisk frig $\varnothing$ relse som skal indfries af kunsten (»drøm«), men perspektivet om en konkret og fysisk frigørelse for de seksuelt udstødte (jvf. »den mørkeste afkrog ingen vil kendes ved «). Identifikationen med de svage og den indeholdte civilisationskritik er således især betinget af forfatterens personlige oplevelse af at tilhøre et marginaliseret og stigmatiseret mindretal. Men den poetiske diskurs udspiller sig ikke i et socialt tomrum, og det lyriske jeg magter ikke at realisere opgøret fuldt ud. I stedet iscenesætter det lyriske jeg sig bag en ny maske, som denne gang tager diskursens form: »Den poetiske løsning på kærlighedens konflikt bliver en iscenesættelse af sig selv bag en maske, som består af et hermetisk billedsprog, der siger sandheden som skjulthed. $\ll^{42}$

På trods af afmagten gav dannelsesrejsens erfaringer Lorca et nyt grundlag at vurdere sin kunstneriske praksis på. Det resulterede i at hans produktion og professionelle aktivitet i de sidste seks år af hans liv i stadig højere grad kom til at orientere sig mod teatret. For Lorca blev teatret løsningen på det uløselige maskespil i hans poetiske tekster, og kom derfor til at repræsentere det artistiske tegns sociale referentialitet. I et interview med Felipe Morales april 1936, godt og vel fire måneder før han henrettes af falangisterne, udtaler han:

»Teatret er poesi, der stiger op fra bogens sider og bliver menneskelig. Og det $g ø r$ den ved at tale og skrige, græde og fortvivle. Teatret behøver skikkelser på scenen, som bærer en poetisk dragt og samtidig lader én se deres knogler, deres blod.« ${ }^{43}$ 
García Lorcas produktion i 30'erne var først og fremmest dette, »poesi, der stiger op fra bogens sider og bliver menneskelig. « Det gjaldt for hans arbejde som direktør for den omrejsende teatertrup La Barraca, der rejste ud til Kastilliens landsbyer og fremførte de spanske klassikere med folkeoplysning for øje. Og det gjaldt hans egen dramatiske produktion i 30'erne, som bl.a. indeholder hans store »rurale trilogi«: Bodas de sangre (Blodbryllup), Yerma og La casa de Bernarda Alba (Bernarda Albas Hus). I kraft af denne menneskeliggørelse genvandt sproget sin sociale referentialitet, og blev et muligt redskab for frigørelse og indsigt. Men samtidig blev det også en trussel for de reaktionære kræfter. Lorca færdiggjorde La casa de Bernarda Alba kun en måned før sin død, og det er svært ikke at læse dette værk som en uheldssvanger forudgribelse af historiens gang. Med militærregimets sejr i borgerkrigen sattes en fyrre år lang parentes i den spanske historie, og dermed også en effektiv stopper for en moderne, progressiv og socialt engageret kunst. I stykket repræsenterer Bernardas yngste datter, Adela, driften, oprøret og poesien. Hun gør oprør mod sin moder og følger sine drifter da hun vælger at give sig hen til den mand hun elsker, selvom han er forlovet med hendes søster. Adela sætter sig således ikke bare op mod sin moder, men mod hele den traditionelle moral. Hun ender dog med at tage sit eget liv fordi hun tror at Bernarda har skudt hendes elsker, og stykket ender med Bernardas replik til sine $\varnothing$ vrige døtre: ${ }^{44}$

»Hold mund, sagde jeg! I kan græde når I er alene. Vi vil alle gå under i et sorgens hav. Hun, Bernarda Albas yngste datter døde som jomfru. Hører I! Stilhed! Stilhed, sagde jeg! Stilhed!«

Således finder García Lorca med sin poetisk-dramatiske diskurs i 30'erne en rebelsk og normoverskridende poetisk sandhed i den kunstneriske diskurs, som, selvom den er mindre eksplicit politisk formuleret end man finder den hos Alberti, sætter lighedstegn mellem tavsheden og repressionen.

\section{Spansk modernisme mellem tradition og fornyelse}

Denne artikel indledtes med en referere til Octavio Paz' beskrivelse af det gensidige modsætnings- og afhængighedsforhold mellem samfundsmæssig modernisering og modernistisk kunst og litteratur. Uden i øvrigt at ville insistere på et direkte forhold mellem de to størrelser, virker det nærliggende afslutningsvis at trække en parallel mellem udviklingen i den politiske konjunktur i Spanien i 20'erne og udviklingen indenfor kunsten. Bevægelsen bort fra den postsymbolistiske purisme og »afhumaniserede « avantgardisme i starten af 20 'erne til en politisk engageret kunst i 30'erne følger nøje den generelle 
politiske konjunktur. I 1923 tager general Primo de Rivera magten ved et statskup, og de følgende par år opnår dette militærregime en vis opbakning ved at sikre den $\varnothing$ konomiske vækst og at indgå fredsaftaler med de socialistiske fagforeninger. Omkring 1925-26 stagnerer den økonomiske vækst, og utilfredshed med regimet dukker op til overfladen: studenterne organiserer sig, fagforeningerne opsiger samarbejdsaftalen osv. Denne protestbevægelse forstærkes frem til 1930, hvor de Rivera må gå af og udskrive demokratiske valg, hvorefter kongen går i landflygtighed i 1931 og republikken dannes. ${ }^{45}$

Det første store skridt i retning af en rehumanisering af kunsten opstår med den spanske surrealisme mellem 1928 og 1930. Den spanske surrealisme opstår ikke som en samlet bevægelse med et programmatisk grundlag, men giver sig udtryk i en række tilsyneladende meget personlige kriser for de involverede kunstnere. Disse personlige kriser kan have forskellige individuelle anledninger, men indebærer for alle de berørte kunstnere at grundlaget for den puristiske kunst tages op til diskussion under indtryk af den ændrede politiske konjunktur. Derfor involverer den spanske surrealisme spørgsmålet om det kunstneriske tegns reference til en virkelighed udenfor tegnet, og derfor er det først på den anden side af denne repræsentationskrise, at digtningen igen bliver i stand til at etablere et direkte og engageret forhold til den sociale og politiske virkelighed. Fra den postsymbolistiske purismes selvreferentielle universer baner den surrealistiske repræsentationskrise vejen for udviklingen af det kunstneriske tegns sociale referentialitet. Modernismens urbane motivkreds gør sin entré filtreret gennem surrealismens hermetiske metaforik, for siden at slå om i politisk engagerede eller ligefrem propagandistiske diskurser.

Spanien er omkring 1930 for første gang siden det syttende århundrede blevet bragt på omgangshøjde med de mest avancerede kunstneriske strømninger i Europa, og spanske kunstnere som Picasso, Miró og Dalí er dominerende på den internationale scene. Selvom flere af de i artiklen nævnte digtere muligvis fortsat forekommer eksotiske for et nutidigt publikum vænnet til den hjemlige kanon af angelsaksiske, franske og tyske forfattere, håber jeg at have vist at Spanien også på det litterære område kan siges at være med helt fremme på dette tidspunkt. Federico García Lorcas produktion, som idag er kendt af et internationalt publikum, er således ikke resultatet af en isoleret, genial kunstnerskikkelses ensomme arbejde, men udtryk for en permanent og intens dialog gruppens medlemmer imellem, mellem digterne indbydes og med de andre kunstnere: kunstmalere, musikere osv.

At Spanien omkring 1930 er bragt på omgangshøjde med den kunstneriske nyudvikling i Europa, betyder imidlertid ikke at der er tale om et identitetsforhold. Det er således bemærkelsesværdigt, at det æstetiske brud med den puristiske kunstopfattelse i Spanien ikke indebærer at digterne vender sig imod den etablerede tradition eller mod de kunstneriske og litterære institutio- 
ner, sådan som Bürger forudsætter det for den historiske avantgarde. I modsætning til de franske surrealister er der ingen af de spanske digtere som opgiver bevidstheden om formens betydning, heller ikke i den surrealistiske fase. Tvært imod har betegnelsen »1927-generationen « netop udgangspunkt i højtideligholdelsen af Góngora dette år, og 27-generationens rødder er vidt forgrenede i den spanske og internationale litterære tradition.

\section{Noter}

1. Octavio Paz: Los hijos del limo, Barcelona 1981, p.10. Egen oversættelse. Et fællestræk ved den umage serie af diskurser som Paz nævner kunne være at de alle ser sproget som et uproblematisk redskab i bestræbelsen på at ændre verden.

2. Jvf. f.eks. Malcolm Bradbury \& James McFarlane: »The Name and Nature of Modernism, « in Modernism, London 1976.

3. Pedro Aullón de Haros: La poesía en el siglo XIXK og La poesía en el siglo XX, Historia y Crítica de la Literatura Hispánica, Madrid 1989, p. 13.

4. Anthony Leo Geist: »La metáfora como estratégia del modernism, « in Lauge Hansen \& Julio Jensen (eds): La Metáfora en la poesía hispánica (1885-1936), Sevilla 1997, p.35. Egen oversættelse. Det efterfølgende citat er fra ibid.

5. Peter Bürger: Theory of the Avant-garde, Minneapolis 1984, p.49. Egen oversættelse. Det efterfølgende citat fra ibid.

6. Betegnelsen »27-generationen « har været kritiseret fordi den stipulerer tilstedeværelsen af en »generation « med de teoretiske og historiske implikationer som dette begreb måtte rumme, og fordi den, måske lidt arbitrært, udpeger året 1927 til at kendetegne gruppen. Da betegnelsen imidlertid har opnået almen anerkendelse, vil den blive anvendt i det følgende. For en problematisering, se f.eks. Gustav Siebenmann: Los estilos poéticos en España desde 1900, Madrid 1973 og Angel González: »La poesía del 27 « in Cuadernos Hispanoamericanos 514-15 (1993).

7. Juan Ramón Jiménez, 1881-1958. Fra 1917 og frem inspireret af bl.a. Paul Valérys poesie pure.Om forholdet mellem Jiménez og Valéry, se f. eks. Antonio Blanch: La poesía pura española, Madrid, 1976. Jiménez fik Nobels litteraturpris i 1956.

8. Juan Ramón Jiménez: Libros de poesía, Madrid 1957, pp.577-78. Egen oversættelse.

9. Rafael Alberti: Marinero en tierra (1925), in Obra completa (OC) bd. I, Madrid 1988 , p.79.

10. Hans Lauge Hansen: »Poetisk metafor som ikonicitet hos Carles Sanders Peirce,« in Metaforer i Kultur og Samfund, Proceedings fra Metafornetværket, Kbh. 1997.

11. Federico García Lorca: Poema del Cante Jondo, skrevet under indtryk af forberedelserne til en flamenco-festival som Lorca arrangerer i samarbejde med bl.a. musikeren Manuel de Falla i 1922 og udgivet i 1931. Egen oversættelse efter Obra Completa (OC) I, Madrid 1986.

12. García Lorca, foredraget »Romancero gitano, OC III p.344.

13. Canelas Newton: »Mitificación y lenguaje poético: El Romancero gitano de García Lorca, « in Revista Hispánica Moderna 48, New York 1995, p.118. Romancero gitano findes i dansk oversættelse, Zigeunerballader, ved Iljitsch Johansen og ved Peer Sibast, Århus 1995. Det efterfølgende citat er fra op.cit., p. 119. 
14. José Ortega y Gasset: La deshumanización del arte, Madrid 1987 (org. 1925). Dansk oversættelse, Kbh. 1945. Bogen er netop genudgivet af Gyldendal, Kbh. 1998.

15. Ultraismen var en bred avantgardestrømning, aktiv i Spanien 1918-1922. Strømningen var inspireret af den italienske futurisme, som i Spanien blev formidlet gennem Ramón Gómez de la Serna. Ultraismen var ligesom futurismen fascineret af fart og bevægelse samt af den moderne teknik og dens maskiner. Creationismen var en strømning hovedsageligt inspireret af kubismen, og i Spanien protagoniseret af chileneren Vicente Huidobro. Denne arbejdede i Paris sammen med Juan Gris, Apollinaire og Reverdy, men fik ved to rejser til Madrid i 1916 og 1918 stor indflydelse på det spanske, litterære miljø. Creationismens centrale idé var, at poesien må skabe, ikke efterligne. Og i dette projekt kommer poeten til at indtage Guds plads som skaberen: »Hvorfor besynger I rosen, Åh, digtere! / Lad den i stedet blomstre i digtet. /.../ Digteren er en lille Gud, «skriver Huidobro i sin poetik »Arte poética« (El espejo de agua, Obras Completas, Santiago de Chile 1964 (org. 1916)). I en spansk sammenhæng er Huidobros lederskab indiskutabelt, og blandt bevægelsens poeter finder vi bl.a. Gerardo Diego. O. 1925 var begge disse »afhumaniserede« avantgardestrømninger på retur, og kunstlivet orienterede sig i retning af en kortvarig tilbagevenden til det figurative maleri inspirereret af Picassos neoklassicisme og til de klassiske litterære former, metrum og strofe etc. Den bedste fremstilling af ultraismen er fortsat Gloria Videlas El ultraismo, Madrid 1971.

16. Gerardo Diego: »Un escorzo de Góngora«, Revista de Occidente nr. 7 (1924). Egen oversættelse.

17. Luis de Góngora: Fábula de Polifemo y Galatea, Madrid 1983, v. 419-20.

18. Federico Garcá Lorca: »Oda a Salvador Dalí«, bragt i Revista de Occidente, april 1926. Herefter forkortet $\gg \mathrm{OSD} \ll$. Egen oversættelse efter $O C$ I, p.953 ff.

19. Hans Lauge Hansen: Ikonicitetens sprakker, Kbh 1996.

20. Rafael Alberti: Cal y canto. Skrevet 1926-28 og udgivet i Madrid 1929. OC I, Madrid 1988, p.331. Alle uddrag af denne samling er i egen oversættelse. Herefter forkortet $C Y C$.

21. $C Y C$ : »Eses de silbos finales / silabarios de los céfiros, / clavadas, rasgando muros / y desclavando los techos «.

22. Federico García Lorca: »Reyerta«. Publiceret første gang i tidsskriftet Verso y pro$s a$, okt. 1926 og inkluderet i Romancero gitano. OC I p.398. Egen oversættelse.

23. »Albacete-knivene... ofte brugt i kamp og blodfejder, er velkendte hvis ikke legendariske og endog mytificerede i den spanske tradition«, Karl Ludwig Selig: Studies on the Romancero gitano, Kassel 1992. Egen oversættelse.

24. Federico García Lorca: »Juego y teoría del duende«, Obras Completas (OC) III, p.311. Oversættelse: Peer Sibast: Troldmanden fra Granada, Århus 1984 p.65.

25. Federico García Lorca $O C$ III p.963. Egen oversættelse.

26. Op.cit. p.965. De to prosastykker blev bragt i det katalanske tidsskrift L'Amic de les Arts nr 18, september 1928 og findes genoptrykt i OC III pp.156-60. Hvad angår den lyriske produktion kan digtet »Oda al santísimo sacramento del altar« (Ode til altrets allerhelligste sakramente) trykt i Revista del Occidente december 1928 og optrykt i $O C$ I pp.960-69 henregnes til den samme poetik.

27. Anthony Geist: La poética de la generacion del 27 y las revistas literarias, Barcelona 1980, »El 27 y la vanguardia: una aproximación ideológica, « Cuadernos Hispanoamericanos, nr. 514-15 (1993) og Geist op.cit. I den sidste artikel argumenterer Geist for den fælles poematiske udvikling ud fra opstillingen af følgende 
før/efter antinomier: glæde vs angst, korte vs lange vers og lys vs mørke (p.40).

28. C.B. Morris: Surrealism and Spain, Madrid 1972, afviser at tale om en spansk surrealisme, mens Vittorio Bodini: Los poetas surrealistas españoles, Barcelona 1982 og Paul Ilie: The Surrealist Mode in Spanish Literature, Michigan 1968, forsvarer begrebet. Blandt de nyere behandlinger kan nævnes Francisco Aranda: El surrealismo español, Barcelona 1981, Lucía García de Carpi: La pintura surrealista, Madrid 1986 og García Gallego: La recepción del surrealismo en Esapña, Granada 1984. Sidstnævnte opsummerer diskussionen i »Surrealismo. El ojo soluble « Litoral nr 174-176 (1987) og gør status over 27-gruppens forhold til surrealismen.

29. Francisco Aranda, op.cit., p.70.

30. Rafael Alberti: Sobre los ángeles, Madrid 1929 og OC I, Madrid 1988. Herefter forkortet SLA. Dansk oversættelse ved Peer Sibast, Om englene, Aarhus, 1988. Hvor intet andet er anført anvender jeg denne oversættelse.

31. SLA, p.444. Oversættelsens sidste vers er korrigeret, idet Sibast, fejlagtigt oversætter »que voy a pinchar sobre«med »som jeg vil stikke i.«

32. Federico García Lorca: »Oda al santísimo sacramento del altar«. Egen oversættelse efter $O C$ I p.968.

33. Federico García Lorca: Poeta en Nueva York, OC I, pp.443-548, udgivet posthumt i 1940. Dansk oversættelse ved Peer Sibast Digter i New York, Kbh. 1983. Hvor intet andet er anført anvendes oversættelser herfra.

34. Henrik Rasmussen: Sandhedens maskespil, Kbh. 1997, p.31. Bogen giver en god overordnet fortolkning af en svær tekst og rummer en række fine analyser, men skæmmes af at Rasmussen ikke kan spansk og har støttet sig på oversættelser.

35. Henrik Rasmussen, op.cit., kapitel 4 samt María Millán: »Voces poéticas de un poeta en Nueva York«, Nueva Estafeta nr. 9-10 (1979).

36. Federico García Lorca, $O C$ I, p.474.

37. Op.cit., p.452. Oversættelsen er ændret i tredie vers, hvor Sibast foreslår »min standsede apolliniske smerte«, men hvor »en tilbageholdt Apollons smerte« langt bedre spiller sammen med tolkningen af Apollon-symbolet som et tegn for den undertrykte homosexualitet.

38. García Posada: Lorca. Interpretación de Poeta en Nueva York, Madrid 1981, p.95.

39. At García Lorca følte sin personlige integritet presset af sin egen sigøjnermyte fremgår af et brev til digteren Jorge Guillén fra januar 1927, hvor han skriver: »Jeg føler mig lidt generet af min sigøjnermyte. Man forveksler mit liv og min karakter. Det ønsker jeg på ingen måde. Sigøjnerne er et tema. Og intet andet.« García Lorca OC III, p.902. Egen oversættelse.

40. García Lorca $O C$ I, p.453. Sibasts oversættelse er ændret i de to sidste vers.

41. Op.cit., p.490. Oversættelsen er ændret i tredie vers, hvor Sibast skriver »menneskekærlighed « som, ikke mindst pba. afhumaniseringsdiskussionen, er noget ganske andet end »menneskelig kærlighed «.

42. Henrik Rasmussen, op.cit. p.64.

43. García Lorca, $O C$ III, p.673: »Al habla con Federico García Lorca« Oversættelse: Sibast, Troldmanden fra Granada, Århus 1984.

44. Federico García Lorca: La casa de Bernarda Alba, OC II, p.1066.

45. Den politiske historie er beskrevet af f.eks. Manuel Tuñón de Lara: Poder y sociedad en España, 1900-1931, Madrid 1992, mens forholdet mellem kunst og samfund kan ses behandlet hos f.eks. Juan Cano Ballesta: La poesía española entre pureza y revolución, Madrid 1972 og hos José Carlos Mainer: La edad de plata, Madrid 1989. 